\section{IIIIB IESE \\ ใ||}

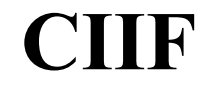

CENTRO INTERNACIONAL DE INVESTIGACION FINANCIERA

EXCHANGE RATES AND TRADE:

HOW IMPORTANT IS HYSTERESIS IN TRADE?

José Manuel Campa*

RESEARCH PAPER No 427

October, 2000

* Professor of Financial Management, IESE

Research Division

IESE

University of Navarra

Av. Pearson, 21

08034 Barcelona 
The CIIF (Centro Internacional de Investigación Financiera) is being set up as a result of concerns from an interdisciplinary group of professors at IESE about financial research and will function as part of IESE's core activities. Its objectives are: to unite efforts in the search for answers to the questions raised by the managers of finance companies and the finance staff of all types of companies during their daily work; to develop new tools for financial management; and to go more deeply into the study and effects of the transformations that are occurring in the financial world.

The development of the CIIF's activities has been possible thanks to sponsorship from: Aena, A.T. Kearney, Caja Madrid, Datastream, Grupo Endesa, Fundación Ramón Areces, Telefónica and Unión Fenosa. 


\title{
EXCHANGE RATES AND TRADE: HOW IMPORTANT IS HYSTERESIS IN TRADE?
}

\begin{abstract}
This paper looks at the responsiveness of a country's export supply to exchange rate changes and measures its quantitative importance by breaking down export adjustments between changes in output levels by existing exporters (intensive margin) and movements due to changes in the number of exporters (extensive margin). Using data on a representative sample of Spanish manufacturing firms, the paper finds sunk costs hysteresis in entry and exit to be an important factor in determining export market participation, but unrelated to exchange rate uncertainty. The sunk costs of entering the market appear to be much larger than the costs of exiting the market. Finally, although hysteresis exists, its effect on the responsiveness of aggregate trade volumes to exchange rate changes is quantitatively small. A 10 percent home currency depreciation results in an increase in export volume due to the increase in the number of exporting firms of only $1.5 \%$ of export volume.
\end{abstract}

I would like to thank William Gentry, William Greene, Mauro Guillén, Charles Himmelberg, Frank Lichtenberg, Mark Pitt, Rama Ramachandran for helpful comments and seminar participants at Brown, Columbia, New York, Rutgers, and Vanderbilt Universities, Fundación Empresa Pública, and the European Economic Association meetings. I also would like to thank Jordi Jaumandreu and Miguel Benavente for helping with the data, Laura Chaqués for research assistance and the Fundación Empresa Pública for providing me access to the data and financial support. Any errors are my own. 


\section{EXCHANGE RATES AND TRADE: HOW IMPORTANT IS HYSTERESIS IN TRADE?}

\section{Introduction}

Exchange rates have fluctuated widely since the breakdown of the Bretton Woods system of fixed exchange rates in the early 1970s. These large fluctuations of exchange rates have led to substantial interest in the effects that exchange rate movements have on a country's export and import behavior and, as a result, on its trade balance. A country's export supply is composed of the aggregation of the export participation decisions of individual firms in that country. Therefore, in order to understand the effects of exchange rate changes on a country's trade balance one must address how such exchange rate changes affect the export supply decision of the average individual firm.

A large theoretical literature exists illustrating the impact of exchange rate movements on the firm's export and import decisions. The basic assumption underlying these models is that a non-exporter must incur an entry cost to enter export markets and that this entry cost is sunk. In a simple world in which exchange rate changes are perceived to be permanent (and future exchange rate uncertainty zero), the firm will enter the export market when the expected gross profits from participating in that market are greater than the sunk entry cost. The firm, however, will not exit the market until the exchange rate reaches the point where the expected gross profits from remaining in the market are negative (1). Baldwin (1988) and Baldwin and Krugman (1989) emphasize this effect and suggest that an asymmetry exists between the exchange rates that trigger entry into and exit from the export market (2).

In a number of papers Dixit elaborated on this idea and showed that the size of the interval between the exchange rates that trigger entry and exit is not constant but is an increasing function of the uncertainty around current exchange rates (3). When faced with the export-participation decision the firm can either enter the export market today (incurring the corresponding entry costs) or wait for a period, observe next period's realization of the exchange rate, and then consider entry again. Therefore, the firm has at every period an option to enter this market. Applying standard analysis from option theory in financial

(1) If sunk exit costs also exist then the negative expected gross profit must be greater in absolute value than the exit costs.

(2) These models were developed to provide an explanation for the asymmetric behavior of the U.S. trade deficit during the 1980s when the increase in the trade deficit during the dollar appreciation in the first half of the 1980s was not reversed after the dollar started to depreciate in 1985.

(3) See the original argument in Dixit (1989) or a review of all the theoretical development surrounding this approach in Dixit (1992) and Dixit and Pindyck (1994). 
economics, Dixit shows that the value of that option increases with the degree of exchange rate uncertainty. The firm will decide to wait for an even more favorable exchange rate realization when the level of uncertainty is high (4). As a result, the range of exchange rates in which neither entry nor exit occurs widens.

An assessment of the empirical relevance of this hypothesis seems specially important given that the deterrent effects that uncertainty around exchange rate movements has on the level of international trade is often cited as one of the major arguments for the recent policy prescriptions in a large number of countries favoring a system of fixed, or managed, exchange rates. This paper uses firm-level data from a sample of Spanish manufacturing firms to quantify the importance of entry and exit hysteresis in export markets. The recent Spanish experience is particularly well suited for a study of this kind. Spain joined the European Exchange Rate Mechanism (ERM) of fixed exchange rates in 1989. Until the fall of 1992, the Spanish peseta was kept within the $6 \%$ bands around its central rate and its volatility decreased significantly relative to previous years. Between September 1992 and May 1993 the peseta devalued its central parity within the ERM by a total of 20\% relative to other major European currencies. In 1995 the peseta underwent a new realignment within the ERM, stabilizing at this new depreciated level afterwards. These devaluations resulted in large changes in the relative prices from exporting and domestic sales. Therefore, although the ERM provided a framework of low expected exchange rate volatility, Spanish firms had to respond to these sharp devaluations of the peseta by evaluating their expected future profitability from exporting and one would expect significant changes in the set of Spanish exporting firms before and after this episode.

Empirical estimation of the importance of sunk-cost hysteresis in determining export supply behavior has been sparse. Most of the literature has focused on asymmetries in the response of trade flows and import (or export) prices to exchange rate changes without explicitly focusing on the entry and exit decision in export markets (5). Studies to date that focus on the effect of exchange rate changes on the entry and exit decision in export markets (the focus of the hysteresis hypothesis) include Campa (1993), Roberts, Sullivan and Tybout (1995) and Roberts and Tybout (1997). These papers find significant support for the hysteresis hypothesis by finding evidence of the existence of sunk costs in entering and exiting the export market. These papers, however, do not measure these entering and existing firms' contribution to aggregate trade flows.

This paper looks at the micro decision of the export participation of the firm. It first estimates a dynamic discrete choice model of the export decision of a firm. The model incorporates two decisions: 1) the export participation decision, and 2) the firm's export supply. The results provide strong evidence for the presence of sunk costs in export markets. The paper then estimates the effects that changes in exchange rates have on the country's aggregate export

(4) An analogous argument applies to the exit decision in the presence of sunk exit costs.

(5) Examples of this literature are Baldwin (1988), Giovannini (1988), Parsley and Wei (1993) and Gagnon(1987). Baldwin (1988) and Giovannini (1988) focus on the response of U.S. import prices to exchange rate changes. Baldwin finds a structural shift in the relationship between U.S. aggregate import prices and the dollar appreciation during the early 1980s. Giovannini also finds evidence of imperfect price changes to exchange rate changes in the U.S. using highly disaggregated import price data. Parsley and Wei (1993) and Gagnon (1987) focus on the behavior of trade flows. Gagnon finds that trade flows have been more responsive to changes in relative prices since the breakdown of the Bretton Woods system. Parsley and Wei use disaggregated trade flows between the U.S. and Canada and find exchange rate volatility (as well as lagged exchange rates) to be insignificant predictors of trade flows. Both of these last two findings are inconsistent with the hysteresis hypothesis. 
supply. If the number of firms entering and exiting the export market is small (or the volume of total trade accounted for by these firms is small), hysteresis might be an important phenomenon at the micro level but not account for a significant proportion of overall trade. Although hysteresis might be important at the firm level, it might not be an important driver of aggregate export supply reactions. The paper estimates an export supply elasticity and breaks down the percentage of that reaction accounted for by changes in the export quantity of those firms that are already exporters (intensive margin) and the percentage accounted for by those firms that either enter or exit the export market (extensive margin).

The lack of contribution to total export supply by new exporters found in this paper contrasts with the findings of recent work by Roberts, Sullivan and Tybout (1995). Using micro data from Colombia, Mexico and Morocco, they found that new exporters were a major factor in explaining the export boom that these countries experienced during the 1980s. They attribute part of this response to credible structural adjustment programs, significant commercial policy reforms and new trade pacts for Mexico and Colombia) as well as exchange rate changes. In our study, the Spanish manufacturing sector was already highly integrated in world markets (6) and, most important, the exchange rate devaluation episode was the only significant policy episode during the sample period. Hence, the emphasis in this paper on the exchange rate effects.

The rest of the paper is organized as follows. Next section presents the basic model describing the export participation decision of the firm and the firm's export supply. Section III deals with some estimation and econometric issues. Section IV presents the data and the sample used to estimate the model. Section V presents the empirical findings. Finally, section VI concludes with some policy implications and directions for future research.

\section{A Model of Export Market Participation and Export Supply}

We will present a model that will capture the basic results highlighted in the hysteresis literature: mainly the presence of sunk costs of entry and exit and the existence of exchange rate uncertainty. In every period t the firm chooses whether to serve the export market $\left(\mathrm{I}_{\mathrm{it}}\right.$ indicator variable that takes the value of 1 if firm $\mathrm{i}$ exports at time $\mathrm{t}, 0$ otherwise) so as to maximize the present discounted value of its profits from exporting

$$
V_{i t}\left(\Omega_{i t}\right)=\max _{I_{i t}, Q_{i t}} E_{t}\left[\sum_{j=\mathrm{t}}^{\infty} \delta^{j-t} \mathrm{R}_{i j} \mid \Omega_{i t}\right]
$$

where $\Omega_{\mathrm{it}}$ is the information set available at time $\mathrm{t}, \delta$ is the one-period discount factor, and $\mathrm{R}_{\mathrm{it}}$ are the expected net revenues from exporting by firm $\mathrm{i}$ in period $\mathrm{t}$. Whenever the firm chooses to export, $I_{i t}=1$, it will also choose its optimal export level $Q_{i t}\left(Q_{i t}=0\right.$ otherwise $)$.

Let's assume that there exist fixed costs of entry $\left(F_{i}\right)$ or exit $\left(G_{i}\right)$ in the export market. Then the revenues from exporting at time $\mathrm{t}, \mathrm{R}\left(\mathrm{I}_{\mathrm{it}}\right)$, are

$$
R_{i t}\left(I_{i t}\right)=I_{i t}\left[\pi_{i t}\left(Q_{i t}, e_{i t}\right)-F_{i}\left(1-I_{i t-1}\right)\right]-G_{i} I_{i t-1}\left(1-I_{i t}\right)
$$

(6) Spain joined the European Union in 1986, and by 1990 most of its commercial barriers were fully aligned with the other European Union members. 
where $\pi_{\mathrm{it}}$ is the gross profit (i.e., not adjusted for sunk costs) from exporting and depends on the value of the exchange rate, $\mathrm{e}_{\mathrm{it}}$ (defined as home currency per unit of foreign currency). The value of $\mathrm{R}\left(\mathrm{I}_{\mathrm{it}}\right)$ depends on whether the firm exported last period or not, i.e., whether $\mathrm{I}_{\mathrm{it}-1}$ was 1 or 0 . If the firm was an exporter last period and still exports this period then $\mathrm{R}\left(\mathrm{I}_{\mathrm{it}}\right)=\pi_{\mathrm{it}}$; and if the firm decides to exit this period then it must pay the exit costs $R\left(I_{i t}\right)=G_{i}$. On the other hand if the firm did not export last year and decides to enter the market this year $R\left(I_{i t}\right)=\pi_{i t}-F_{i}$.

There are several assumptions built into equation [2] that are worth mentioning. The costs of entry and exit are time invariant. In principle, these costs might change over time as overall market integration increases and transportation and communication costs decrease. These costs are also assumed to be paid only in one period. In particular, one might think that the export decision would involve a sequential process by which the firm pays an initial sunk cost for exporting and then has to incur additional costs if it remains in the market. These costs are also independent of the firm's history beyond the previous year. Therefore, a firm that has been an exporter in the past, exited the market and now decides to reenter, has to incur the same entry costs as a completely new exporter (the same applies for the exit side). Finally, these costs represent the costs of serving the "export" market. The definition of this export market might vary by firm, depending on the country of final destination of the firm's exports. Variability in market destinations is allowed across firms by allowing the entry and exit costs $F_{i}$ and $G_{i}$ to be firm specific. However, one can well imagine that within a firm there might also exist cross-country variability in sunk costs depending on the final market of destination, and that variability is not captured in the model (7). satisfies

Using Bellman's equation to solve equation [1], we know that $\mathrm{I}_{\mathrm{it}}$ must be such that it

$$
V_{i t}\left(\Omega_{i t}\right)=\max _{I_{i t}}\left[R_{i t}\left(I_{i t}\right)+\delta E_{t}\left[V_{i t+1}\left(\Omega_{i t+1}\right) \mid I_{i t}\right]\right]
$$

We can solve for the first order condition of this problem and we get that firm i will decide to export when

$$
\begin{gathered}
\pi_{i t}\left(Q_{i t}, e_{i t}\right)+\delta\left[E_{t}\left[V_{i t+1}\left(\Omega_{i t+1}\right] \mid I_{i t}=1\right)-E_{t}\left[V_{i t+1}\left(\Omega_{i t+1}\right) \mid I_{i t}=0\right]\right] \geq \\
F_{i}-\left(F_{i}+G_{i}\right) I_{i t-1}
\end{gathered}
$$

From equation [4] one can get the export participation decision of the firm. A firm will export as long as the left-hand side of this equation is greater than the right-hand side. The left-hand side captures the benefits from exporting, which are the expected gross profits at time $t$ and the present value of the increase in the future value of the firm by becoming an exporter. The expected costs are either the entry costs if the firm was not an exporter last period, $\mathrm{I}_{\mathrm{it}-1}=0$, or the benefit of avoiding the exit costs otherwise.

This equation has several implications worth pursuing. The dynamic content of this decision depends only on the presence of entry and exit costs. If sunk costs are zero then equation [4] collapses to $\pi_{\mathrm{it}}\left(\mathrm{Q}_{\mathrm{it}}\right)>=0$ (since $\mathrm{E}_{\mathrm{t}}\left[\mathrm{V}_{\mathrm{it}+1}\left(\Omega_{\mathrm{it}}+1\right) \mid \mathrm{I}_{\mathrm{it}}=1\right]-\mathrm{E}_{\mathrm{t}}\left[\mathrm{V}_{\mathrm{it}+1}\left(\Omega_{\mathrm{it}}+1\right) \mid \mathrm{I}_{\mathrm{it}}=0\right]=0$ ) and the firm export decision will be a purely static decision process. As a result, one can test for the presence of sunk costs by looking to see whether state dependence exists in the export participation decision or not, i.e. if the probability that firm $i$ is an exporter at time $t$ depends on

(7) Roberts and Tybout (1997) allow the entry costs to be a function of the history of export experience of the firm. 
whether the firm was an exporter at time $\mathrm{t}-1$ or not. Second, the gross profits of the firm at time $t$ are only a function of the current exchange rate $e_{i t}$. This implies that conditional on being an exporter, the firm's choice of output at time t is purely a static decision that has no impact on the future value of the firm (8). Third, changes in the expected future exchange rate process will have implications for the entry and exit decision but they will not affect this period's export quantities of existing exporters. In particular, changes in the volatility of the exchange rate $\sigma_{i t}$ will affect the option value of entering or exiting the market but, conditional on the firm being an exporter, will have no effect on this period's export quantity. As a result, any effect of exchange rate volatility on export supply will all be due to the extensive margin.

The firm's entry and exit decisions depend on the current value of the exchange rate and on its conditional distribution. The current value of the exchange rate affects the expected profits from exporting this period. The conditional distribution affects the expected value in the future from being an exporter or not. The export volume of an exporter in period $t$ depends only on period t's exchange rate, while the decision to remain in the export market depends on both $\mathrm{e}_{\mathrm{it}}$ and the conditional distribution of the future exchange rate.

Conditional on the firm being an exporter at time $t$, the firm also chooses export output so as to maximize its current gross profits from exporting. Since current output has no effect on future export decisions, as long as it is positive, this is a purely static decision that depends only on observable firm characteristics included in the firm's information set at time t. Given this information the firm will choose the $\mathrm{Q}_{\mathrm{it}}$ that maximizes

$$
\operatorname{Max}_{\hat{Q}_{i t}} p_{i t}\left(Q_{i t} \mid W_{i t}, I_{i t}=1\right)
$$

Consider a population of homogeneous firms, each of them facing the same decision at time t. Since all firms are identical, the solution to the export participation decision will be identical for every firm in the sample and, as a result, the export supply of the country will be either 0 , or the sum of the export choices of all firms (which will be the optimal quantity exported by each firm times the number of firms). However, since firms are heterogeneous we can condition that heterogeneity and solve the export participation decision as the sum of the individual export decisions of all firms. For a given exchange rate and set of individual firm characteristics the expected export supply of the firm will be its optimal output $Q_{i t}$ determined by equation [5] times the probability that the firm will be an exporter at time $t$, i.e. $\mathrm{I}_{\mathrm{it}}=1$. Therefore, for each firm $\mathrm{i}$, its expected export supply will be:

$$
E_{t}\left(Q_{i t}\right)=\hat{Q}_{i t}\left(\Omega_{i t}\right) \operatorname{Pr}\left(I_{i t}=1 \mid \Omega_{i t}\right)
$$

the country's export supply will be the sum of all the individual export decisions of all firms.

To estimate the effect of an exchange rate change on the expected export from each firm $i$ we can compute the elasticity of the export supply relative to the exchange rate, $\eta_{\mathrm{Q}, \mathrm{e}}$. For each firm i this elasticity will be

$$
\frac{\delta E_{t}\left(Q_{i t}\right)}{\delta e_{i t}}=\frac{\delta \hat{Q}}{\delta e_{i t}} \operatorname{Pr}\left(I_{i t}=1\right)+\hat{Q}_{i t} \frac{\delta \operatorname{Pr}\left(I_{i t}=1\right)}{\delta e_{i t}}
$$

(8) In particular, dynamic dependence of current profits from exporting on lagged or future export volume is not allowed. Froot and Klemperer (1989) present a model and its implications for export pricing when such dependence is allowed. 
Therefore, an exchange rate change can affect the expected export of a firm $\mathrm{i}$ in two distinct manners: 1) by changing the optimal export level that an exporting firm will decide to export (intensive margin); and 2) by affecting the probability that the firm will choose to be an exporter this period (extensive margin). In the following sections, we will estimate this export supply choice and provide some estimates of the relative size of each of these effects for a sample of Spanish industrial firms.

\section{Empirical Implementation}

The estimation of the export supply equation has two components: 1) the export market participation condition of a firm; and 2) conditional on being an exporter the relationship between export volume and exchange rate changes. We model the export supply function conditional on being an exporter as a simple static linear function of exogenous variables and an error term

$$
\begin{array}{lr}
Q_{i t}=\alpha_{0}+\alpha X_{i t}+v_{i t} & \text { if } I_{i t}=1 \\
Q_{i t}=0 & \text { otherwise }
\end{array}
$$

where $X_{\text {it }}$ are observable exogenous variables and $\alpha_{0}, \alpha$ are parameters and $v_{\text {it }}$ is an error term.

The export market participation decision $\mathrm{I}_{\mathrm{it}}$ in equation [4] can be summarized by expressing equation [4] with the following discrete choice dynamic equation:

$$
I_{i t}=\left[\begin{array}{l}
1 \text { if } \pi_{i}\left(e_{i t}, Q_{i t}\right)+\delta\left[E_{t}\left[V_{i t+1}\left(\Omega_{i t+1}\right) \mid I_{i t}=1\right]-E_{t}\left[V_{i t+1}\left(\Omega_{i t+1}\right) \mid I_{i t}=0\right]-F_{i}+\left(F_{i}+G_{i}\right) I_{i t-1} \geq 0\right. \\
0 \text { otherwise }
\end{array}\right][9]
$$

This equation can be estimated structurally if we are willing to provide a particular process for the exchange rate and a particular form of the per-period profit function (9). Given our interest in the export supply function of equation [8] rather than the dynamic problem in equation [9] we will follow a reduced form specification for the export choice. However, equation [9] provides the basic results for testing the hysteresis hypothesis (Roberts and Tybout 1997). A test of hysteresis is equivalent to a test of whether state dependence exists in the export participation decision. If sunk costs of entry and exit are zero (i.e. no hysteresis) then the coefficient on previous export market participation, $\mathrm{I}_{\mathrm{it}}-1$, should be zero. The coefficient on this variable measures the sum of entry and exit costs, i.e. the "hysteresis band" when the volatility of the exchange rate is zero.

We can pursue estimation of equation [9] by assuming a reduced form for the value of the firm from exporting minus the fixed costs of entry. We will assume that the expected gain from exporting behaves according to the following equation

$$
\begin{gathered}
\pi_{i}\left(e_{i t}, Q_{i t}\right)+\delta\left[E_{t}\left[V_{i t+1}\left(\Omega_{i t+1}\right) \mid I_{i t}=1\right]-E_{t}\left[V_{i t+1}\left(\Omega_{i t+1}\right) \mid I_{i t}=0\right]-F_{i}+\left(F_{i}+G_{i}\right) I_{i t-1}=\right. \\
\mu_{t}+\beta_{0} e_{i t}+\beta_{1} Z_{i t}+\left(\beta_{2}+\beta_{3} \sigma_{i t} I_{i t-1}\right)+\varepsilon_{i t}
\end{gathered}
$$

(9) Eckstein and Wolpin (1989) and Rust (1994) survey the methodology of applications of estimation of structural models of dynamic discrete choice. 
where $\beta_{\mathrm{i}}$ are parameters to be estimated, $\mathrm{Z}_{\mathrm{it}}$ is a vector of observable characteristics of firm i at time $t, \sigma_{i t}$ is the conditional variance of the exchange rate for firm $i$ at time $t$, and $\varepsilon_{i t}$ is an unobservable term.

The term $Z_{i t}$ is an annual time effect reflecting temporal variations in export profitability that are common to all firms in the sample. These effects control for common shocks such as changes in the business cycle, trade liberalization across all industries (such as the creation of the European Common Market in 1992), and overall changes in demand for Spanish exports. The term $\mathrm{Z}_{\text {it }}$ captures factors that are firm specific and affect the export decision of a particular firm. It captures the effects of the fixed costs of entry, the firm variable costs of exporting, and other firm specific effects. The variables most important for our purpose are the exchange rate variables $\mathrm{e}_{\mathrm{it}}$ and $\sigma_{\mathrm{it}}$. The volatility of the exchange rate enters the export participation decision by altering the expected value of the firm under the two alternative scenarios of being an exporter or not. It does not affect the current level of exports for the exporting firm, since the contemporaneous exporting decision is purely a static decision. However, the width of the hysteresis band should increase the higher the level of exchange rate uncertainty faced by the firm $\sigma_{\text {it }}(10)$. On the other hand, changes in the current exchange rate affect both the current profitability from exporting and, to the extent that they affect expectations of future exchange rates, the expected future value from being an exporter. Therefore, transitory changes in exchange rates would have a lower effect on export volume than equivalent permanent exchange rate movements. Current exchange rate changes not only affect current profits from exporting; they also affect the expectation of the future value of exporting by changing the firm's conditional expectations of the future exchange rate.

These two variables are firm specific depending on the relevant exchange rate changes of the peseta relative to the firm's export markets (11). For each firm we need information on the contemporaneous real exchange rate relative to its export markets, and on the firm's expectation of the future exchange rate process based on information available at time t. For exporting firms we compute the firm's relevant exchange rate as a weighted average of the bilateral exchange rate between the dollar and the currency of destination of the firm's exports, where the weights are the proportion of the firm's exports to each destination market (12). For non-exporting firms we define the destination market as the four countries with the largest amount of Spanish exports in 1990 in the industry in which the firm performs its primary operations. Once we observe the firm specific exchange rates, we estimate a time series process for each of the exchange rates so that we can obtain an estimate of $\sigma_{i t}$ for each firm and time period conditional on the information available to the firm at time $\mathrm{t}(13)$.

Econometric Issues: We will perform the joint estimation of equations [8] and [10]. Two issues need to be addressed. First, the estimation of equation [10] involves a test of the hypothesis that past participation in export markets affects today's probability of being an exporter (a lagged dependent variable). To guarantee that we get an appropriate estimate of this coefficient we need to control for all other determinants of export participation that are

(10) The width of the hysteresis band will increase with any increase in the uncertainty of expected profits from exporting, not only with exchange rate uncertainty. However, we are not allowing any other source of firm-specific uncertainty to significantly change over the sample period.

(11) In the Appendix we explain in greater detail the exact computation of these exchange rate variables.

(12) These weights are available for firms that were exporters in 1990 and/or 1994. See the data appendix for details on the construction of the weights.

(13) As stated above, current exchange rates might be perceived to be permanent or transitory with different implications for the expected future value of exporting. 
persistent over time. To a large degree, these factors are being controlled by the inclusion of all other exogenous variables of the firm that predict export performance. However, to the extent that other left-out variables are persistent determinants of export participation, there will be serial correlation in the error term $\varepsilon_{\mathrm{it}}$. If the error term is serially correlated, then a correlation will be incorrectly attributed to past export participation, causing the coefficient on past export participation to be significant and overstating the presence of sunk costs (14).

Second, we need to specify the structure of the error terms in these two equations. We allow for serial correlation in both equations by allowing for a random effect component in each equation. In the export participation equation we assume that the error term $\varepsilon_{i t}$ is the sum of two normally distributed random components: a firm-specific component and a white-noise component: $\varepsilon_{\mathrm{it}}=\alpha_{\mathrm{i}}+\varphi_{\mathrm{it}}$. The firm specific component captures all unobservable time-invariant components of export participation such as managerial characteristics, foreign experience, product quality, and other factors that induce persistent plant-specific differences in returns from exporting. We normalize $\operatorname{var}\left(\varepsilon_{i t}\right)=1$, and assume that $\operatorname{cov}\left(\alpha_{i}, \alpha_{k}\right)=0$. The correlation between successive disturbances for the same individual is $\rho_{\mathrm{i}}$, so that the covariance between different time periods for a single plant and the fraction of the variance of the error term $\varepsilon_{i t}$ that arises from the permanent component in the error are the same. We assume that the error structure on the export supply equation follows a similar structure, $v_{i t}=u_{i}+z_{i t}$, where both $u_{i}$ and $\mathrm{z}_{\mathrm{it}}$ are normally distributed with zero-mean and variances $\sigma_{\mathrm{u}}, \sigma_{\mathrm{z}}$. We further restrict the correlation between the error components in equations [8] and [10] and assume that only the random effects are correlated for a given firm so that $\operatorname{cov}\left(u_{i}, \alpha_{k}\right)=\rho$ for $i=k$ and zero otherwise and $\operatorname{cov}\left(\mathrm{u}_{\mathrm{k}}, \varphi_{\mathrm{kt}}\right)=\operatorname{cov}\left(\mathrm{a}_{\mathrm{k}}, \mathrm{z}_{\mathrm{kt}}\right)=\operatorname{cov}\left(\varphi_{\mathrm{k}}, \mathrm{z}_{\mathrm{kt}}\right)=0$. Given this, $\varepsilon_{\mathrm{it}}$ and $\mathrm{v}_{\mathrm{it}}$ are jointly distributed as a bivariate normal distribution with correlation $\rho$.

This model can be estimated by maximum likelihood. However, estimation by maximum likelihood involves the computation of a double integral resulting from the need to numerically integrate the two random components in the system. The estimation of such a system is extremely burdensome. Instead, we follow the two-stage approach suggested by Heckman (1981a). First, we estimate the export participation equation as a single equation. This equation is a dynamic random effects probit model and it can be estimated by maximum likelihood using the approach proposed by Butler and Moffit (1982). We then estimate the second equation after controlling for the self-selection into exporting implied by the export participation decision. The expected value of the quantity exported given the exogenous variables and the variance of the disturbance term $v_{i t}$ in equation [8] are

$$
\begin{aligned}
& E\left[\mathrm{Q}_{i t} \mid \mathrm{I}_{i t}=1\right]=\alpha^{\prime} X+\rho \sigma_{v} \lambda\left(\beta^{\prime} \mathrm{Z}\right) \\
& \operatorname{var}\left(v_{\mathrm{i}}\right)=\sigma_{v}^{2}\left(1-\rho^{2} \lambda_{\mathrm{i}}\left(\lambda_{\mathrm{i}}+\beta \mathrm{Z}_{\mathrm{i}}\right)\right)
\end{aligned}
$$

where $\lambda()=.\phi() /.[1-\Phi()$.$] with \phi$, and $\Phi$ representing the density and cumulative distribution function of the standard normal and the other variables are represented in vector notation. We can estimate this second equation by a random effects model. However, the error covariance matrix of this equation needs to be corrected for the heteroskedasticity implied in equation [11] and by the fact that the term $\lambda($.$) is actually not observed data, but an estimate$ from the first stage discrete choice analysis. We follow Greene (1981) for computing the appropriate variance-covariance matrix.

(14) This is the problem of distinguishing between serial correlation of the error term and true state dependence that might result in "spurious" state dependence. See Heckman (1981a) for an explanation. 
We still have the additional problem that in the first period we cannot treat lagged export participation as exogenous because it obviously depends on $\alpha_{i}$. Heckman (1981b) proposes using an approximate reduced-form representation for $\mathrm{I}_{\mathrm{i} 90}$ in the first year and allowing the disturbance terms on that first period to be correlated with the errors for the rest of the time periods. We included such an estimation procedure by reducing $\mathrm{I}_{\mathrm{i}, 90}$ to be a linear function of exogenous observable variables of firm $i$ and by allowing for a correlation between $\varepsilon_{\mathrm{i} 90}$, and $\varepsilon_{\mathrm{it}}(15)$.

Finally we need to specify the exogenous variables that conform the matrix $X_{i t}$ and $\mathrm{Z}_{\mathrm{it}}$. For the export supply decision, the variables included are the firm specific exchange rate $\mathrm{e}_{\mathrm{it}}$, the $\log$ of domestic sales of the firm, the investment to sales ratio, the firm's ratio of employee compensation to value of sales, and a dummy that takes a value of 1 if the firm had foreign ownership and zero otherwise. The exogenous variables in equation [10] include a set of industry dummies, an interaction between time specific effects and previous export market participation decisions of each firm, and a set of firm specific exogenous variables. The set of exogenous variables included are: the percentage of foreign capital participation in the firm's capital, the ratio of investment to sales of the firm, the firm's (log) volume of domestic sales, a firm-specific exchange rate level and its expected conditional variance.

\section{Sample and Data}

The data come from a longitudinal study of Spanish manufacturing firms started in 1990. The sample period covers the interval 1990-1997. The study follows a sample of initially 2188 firms with information collected annually from each firm (16). In 1990, the first year of the study, a larger and more detailed survey on the firm's overall activities was administered. The information collected each year is consistent with previous years. The sample of firms included is representative of the population of manufacturing firms in the Spanish economy. Firms that drop out of the original sample are replaced every year by firms with similar characteristics from the population (17). The sample contains information for every year on each firm's volume of sales, costs, financial performance and export volume among other variables. The study is expected to administer the more detailed questionnaires once every four years. In 1990 and 1994, information was collected on each firm's export markets of final destination for its products.

Table 1 contains information on the distribution of exporting firms by industry and size. Across industries, office equipment, chemical products, leather and leather products and miscellaneous manufacturing products show a slightly higher propensity to export by smaller size firms. Propensity to export increases consistently with the size of the firm. In 1990 , less than a third of all firms with less than 50 employees were exporters, while more than 80 percent of firms with more than 200 employees exported. The overall number of exporting firms was slightly less than half (1026 companies out of 2188). Although large firms are more likely to export, the share of exports in total sales is not an increasing function of firm size. The last row of Table 1 indicates the average share of exports in total firm sales by each firm size group. Export intensity shows a non-linear relationship with firm size, with

(15) We included as exogenous variables for this initial state $I_{i, 90}$ the sales of the firm, the ratio of $R \& D$ to sales, the growth in sales, and the proportion of non-skill employment.

(16) The project has been directed by the Fundación Empresa Pública with the financial support of the Spanish Ministry of Industry.

(17) See MINER (1993) for a detailed description of the database. 
the highest export intensity among mid-size firms with between 100 and 200 employees. This non-linear relationship also holds across different industries.

Table 2 shows the distribution of exporting and non-exporting firms through the period of the study. The number of exporting firms has increased slightly during this period, although due to attrition in the number of firms over time, the proportion of exporting firms has increased from $47.7 \%$ in 1990 to $61.7 \%$ in 1997 . The average exporting firm is considerably larger than the average non-exporting firm, and the difference in size between these two groups has been increasing over time. By 1997, exporting firms accounted for $96.4 \%$ of total sales in the sample.

The second panel of Table 2, shows the behavior of the peseta relative to the dollar, the ECU, and the real effective exchange rate of the peseta relative to a trade weighted-basket of currencies. The peseta joined the Exchange Rate Mechanism (ERM) of the European Monetary System (EMS) on June 19th, 1989, fixing its exchange rate relative to other European currencies around a central rate, with a $6 \%$ fluctuation band. This central rate remained unchanged until the fall of 1992, when the peseta was forced to devalue twice. We can see this evolution from the behavior of the peseta/ECU exchange rate during the period, which is quite stable, with a significant devaluation in the 1992-1993 period followed by another realignment in the central rate of the peseta in the ERM in 1995 (18). In real terms, the peseta underwent a small appreciation between 1989 and 1992 due to the higher level of Spanish inflation relative to its major European trading partners, followed by a continuous small annual real depreciation from then on. Relative to the dollar, the peseta had maintained a reasonable level of nominal stability until its devaluation relative to other ERM currencies in September and November of 1992.

Export participation shows a high level of persistence across firms in the sample. Table 3 a shows the transition probabilities for firms in the sample from being an exporter in one year to either being an exporter again next year or stopping export behavior. Each row describes the transition from the exporting status in column 1 to the status in column 2 . The entries in the table are the proportion of firms in each of the period t categories that choose each of the two possible alternatives the following year. For instance, the top row for the 1990-1991 column indicates that 92 percent of those firms that did not export in 1990 also did not export in 1991. The last row indicates that more than $93 \%$ of the firms that exported in 1990 continued to export in the following year. Clearly, there is a substantial amount of persistence in export status over time across firms in the sample, specially for exporting firms. There is also a significant difference in the export volume of firms that enter and exit the export market. Table $3 \mathrm{~b}$ breaks down the percentage of firms in the sample that enter and exit the export market in every year relative to all firms in the sample and their contribution to total sample sales and exports. Firms entering the export markets account for less than $1 \%$ of total exports the first year they enter the export market. Exiting firms accounted, in their last year in the export market, for a small percentage of total exports, indicating that their export volume had significantly declined prior to their decision to exit the market. This asymmetry in the export volume of new exporters and new non-exporters suggests the presence of a cost of entering and exiting the export markets.

Persistence in export status, however, is not direct evidence for the presence of hysteresis. It can be caused by cross-firm differences in profitability that result in

(18) Campa and Chang (1996) provide a description of the behavior of the peseta within the EMS during this period and whether the peseta devaluations were anticipated or not. 
significantly different payoffs from exporting for different firms. In order to be able to discriminate among these two possible hypotheses we need to control for other firm specific factors in the context of the econometric specification above.

Computation of firm specific exchange rate processes: each exporting firm is exposed to its own specific exchange rate process depending on the behavior of the bilateral exchange rate between the peseta and the currency of the destination market(s) for the firm's exports. The relevant exchange rate variable for the firm will be an index that measures some sort of weighted average of the behavior of the bilateral exchange rates of each potential export market. This potential index, however, is hard to calculate since we only observe the market of export destination for those firms that are exporters. Estimating effective exchange rates for non-exporting firms is most difficult since the effective markets are potential markets that have not been observed yet. Even computing effective exchange rates based on observed export patterns of exporting firms is probably also inappropriate since the weights themselves depend on the behavior of the exchange rate and are therefore endogenous (19). In our data, this computation of firm specific exchange rates is actually complicated by the fact that we only observe the breakdown of export markets twice, at the beginning of the sample and in 1994, and that we don't observe a complete disaggregation of all destination markets (20).

We compute individual exchange rate processes for each firm that was an exporter in 1990 and 1994 by taking its effective export market to be the average of its actual markets in those two periods. For firms that were non exporters in 1990(1994) but exporters in 1994(1990), their market is defined as their 1994(1990) export patterns. For non-exporting firms in 1990 or 1994 we assume that their effective markets are equal to the observed export patterns of that industry in 1990 and we compute a weighted average of the four largest destination markets for the industry.

Once we identify the relevant exchange rate index for each firm i, we need to get an estimate of the distribution of that exchange rate process over time, since the expected change in the future value of the firm depends not on the current value of the exchange rate today but on the conditional expected distribution of the exchange rate in the future. We assume that each exchange rate process is normally distributed with conditional mean and variance $\mu_{\mathrm{it}}$ and $\sigma_{\mathrm{it}}$. We follow the literature on exchange rate determination and assume that the exchange rate process is well represented by a $\operatorname{GARCH}(1,1)$. Using data on monthly observations from January 1980 to December 1989 we estimate, for every firm, the parameters of the $\operatorname{GARCH}(1,1)$ process and use these estimated parameters to forecast at the beginning of each year in the sample what the expected average conditional variance for that year will be based on the firm-specific exchange rate behavior up until the end of the previous year. For the expected mean of the exchange rate, we assume all exchange rate changes to be permanent and use the current exchange rate $e_{i t}$ as the expected exchange rate in the future (21).

(19) The same is obviously true for the exchange rate volatility measure, $\sigma_{i t}$.

(20) The Appendix describes in detail the computation of the firm-specific exchange rate series.

(21) The assumption of the exchange rate following a random walk seems appropriate for exchange rates. We also tested for the robustness of our estimated conditional volatility by estimating the conditional volatility as the standard deviation of the log differences of the monthly firm-specific exchange rate during the previous one and two years, and the results did not qualitatively change from those reported below. 


\section{Econometric Results and Discussion}

Table 4 presents the results from the estimation of the probit model on the export participation decision of the firm. The third column in Table 4 reports the results from the basic specification. The first two columns report the results from a specification in which we exclude the exchange rate variables. The coefficient on previous export experience $\left(\mathrm{I}_{\mathrm{it}-1}\right)$ is always positive and highly significant, suggesting the presence of considerable sunk costs in export markets. When we compare the interaction of time effects with previous export participation, the coefficient on the interaction effects shows no consistent pattern at the beginning of the sample, becoming positive and significant for the later years. This effect might reflect the increase in export persistence over time described in Table $3 \mathrm{a}$ above.

The exchange rate effect is positive and significant as expected (remember that the exchange rate is the peseta price of foreign currency, therefore an increase in value implies a peseta depreciation) (22). This effect is very robust across all specifications and suggests that even after controlling for the year-specific shocks, firms reacted to fluctuations idiosyncratic to their specific exchange rate.

The last two columns report the effects of including the volatility of the exchange rate as an independent exogeonous variable and interacted with the lagged export participation. The coefficients on exchange rate volatility are never significant. However, the interaction effect between sunk costs and exchange rate volatility is negative and significant. This suggests that export persistence was lower in periods of high exchange rate volatility. This finding is not surprising given that exchange rate volatility was high during the peseta devaluations of 1992 and 1993, which coincided with a large economic recession in the Spanish economy (23). A likelihood ratio test rejects at the 5 percent level the null hypothesis of all coefficients on the exchange rate volatility variable being equal to zero. However, a likelihood ratio test of this null vs. an unrestricted model that also includes interaction effects between year dummies and previous export market participation (such as column 4) cannot reject this null hypothesis.

Finally, the coefficients on the exogenous components of firm characteristics show the expected behavior. Domestic size of the firm (LSALES) is a positive predictor of export intention, once previous export behavior has been controlled for. The percentage of foreign capital participation (KEXTR) also has a positive effect (although not always significant) on the probability of exporting, as does the percentage of non-skilled workers in the industry. Finally, the investment intensity of the firm (INV) does not seem to significantly affect the probability of entry.

Table 5 reports the results of estimation of the export supply in equation [8] taking into account the sample selection induced by equation [10]. As can be seen from the point estimates, the exchange rate has a significant positive effect on the volume of exports across all specifications. This effect implies that a peseta depreciation increases the amount of exports. A number of the firm characteristics help predict the volume of exports. The size of domestic sales is a positive predictor of export performance, with a coefficient around 1.1, which suggests the tendency of larger firms to be exporters. Firms with foreign capital

(22) Given that the exchange rate variable is firm-specific a large part of the identification comes from crosssectional variation in the data. As such, the choice of base year might matter. We estimated the results using two base years, 1985 and 1990, and the results were robust to the choice of base year. The results reported here use 1985 as the base year.

(23) Industrial production in Spain fell by 7\% between 1991 and 1993 (see the last row of Table 2). 
participation (24) (KINT) also have a higher volume of export than similar firms that are completely owned by domestic investors. Our proxy for variable costs of production, the ratio of employee compensation to sales (WAGES), does not help predict export performance. We also tried to include (not reported) the level of the firm research and development expenses and the percentage of nonskilled workers in the labor force (25). Both of these variables tended to be positive predictors of export performance. However, their contribution to the whole model was marginal.

Our model assumes that export supply is a static problem and that sunk costs and hysteresis only exist for the entry/exit decision. However, an alternative hypothesis might suggest the presence of hysteresis on the quantity of export as well as on entry and exit into the export market. This might be due to the presence of sunk cost or to some other real rigidity that makes, for instance, market share maintenance a desirable goal (26). In columns (3) and (4) of the table we include the firm-specific volatility and lagged export volume of the firm. If these variables were significant it would provide some support for the view that export persistence exists. The coefficient on the exchange rate volatility variable has no effect on export volume while the lagged dependent variable has a marginally significant positive sign (27). This lack of effect of exchange rate volatilty suggests not only that volatility does not appear to affect the value of the entry and exit option but also that it does not affect the current level of exports. This result provides some support for the modelling strategy in the previous section, which did not include volatility effects as having any effect on the export quantity conditional on the firm being an exporter. The significant effect of the lagged dependent variable suggests that some persistence on export volume such as that suggested by Froot and Klemperer (1989) might exist.

In order to address the effect of the presence of hysteresis on the relationship between export volume and changes in the exchange rate of the country, we need to estimate what the effect would be of an exchange rate movement. We need to break down the overall effect on export volume into the two distinct effects: the change in the export volume of existing exporters (intensive margin), and the change in volume due to changes in the number of exporting firms (extensive margin). We compute this for different values of the exchange rate, and evaluate this elasticity both for the average firm in the sample and for the average of the quartiles of the distribution of firm size as measured by the firm level of domestic sales (28). We assume that the exchange rate was at its purchasing power parity equilibrium level in June 1989 and compute the effects of a 10 percent and a 20 percent movement of the exchange rate in either direction on the trade volume. We choose the PPP exchange rate value of June 1989 since that is when the peseta decided to join the Exchange Rate Mechanism of the EMS, fixing its exchange rate relative to its major trading partners.

Table 6 reports the estimated elasticities evaluated for the whole sample, and for the average of each of the four quartiles. For each exchange rate change, the table reports three numbers: the overall elasticity, and the percentages of this elasticity due to the intensive margin and to the extensive margin. The average exchange rate elasticity is relatively high,

(24) KINT is a dummy variable that takes the value of 1 if KEXTR $>0,0$ otherwise.

(25) Notice that investment intensity is highly correlated with nonskilled workers. In fact, dropping the latter results in a positive and significant coefficient on the former.

(26) Froot and Klemperer (1989) provide an example of such a model.

(27) The inclusion of the lagged-dependent variable in column (4), given the structure of the error term, requires an instrumental variable estimation. We use the estimator proposed by Arellano and Bond (1991) for dynamic panel data models.

(28) We also tried breaking down the sample by the firm's number of employees with very similar results. 
oscillating around .8. However, most of the change in export volume is not due to changes in the number of exporters but to the intensive margin. On average only 20 percent of the change in export volume due to an exchange rate devaluation of 20 percent is due to the increase in the number of exporters. If the peseta depreciated only by 10 percent then the change in export volume due to the increase in the number of exporters will be only 1.5 percent (21 percent of the overall export change of $7.7 \%$ ). As expected, the extensive margin is relatively more important for smaller firms than for large firms, since the probability that a firm is already an exporter increases with firm size.

There are significant differences in the composition of the exchange rate elasticity depending whether the exchange rate appreciates or depreciates. For a given percentage change in the exchange rate, the extensive margin is always more important if the change is an appreciation of the peseta rather than a depreciation. This result suggests the existence of significantly higher sunk entry costs than exit costs and is consistent with the observed evidence on export performance by firms that exit the export market in the years prior to exiting the market.

\section{Conclusion}

This paper has looked at the empirical role of exchange rate hysteresis in affecting the responsiveness of export supply to exchange rate changes. The paper tests for the existence of hysteresis in export markets and then provides estimates on the empirical relevance of hysteresis on a country's trade volume responsiveness to exchange rate changes. The analysis breaks down export adjustments between changes in output levels by existing exporters and movements due to changes in the number of exporters. Using data on a representative sample of Spanish manufacturing firms, the paper finds sunk costs hysteresis to be an important factor in determining export market participation. We find, however, that the degree of hysteresis does not appear to be related to the degree of exchange rate uncertainty faced by the exporter. Finally, although hysteresis exists, its effect on the responsiveness of the volume of trade to the degree of exchange rate changes is quantitatively fairly small. A 10 percent peseta depreciation increases export volume due to increases in the number of exporting firms by only $1.5 \%$ of export volume.

The results in the paper suggest that trade adjustments due to exchange rate changes mainly occurred through the adjustment of quantities by existing exporters rather than through changes in the number of exporting firms. The emphasis in this paper has been on the implications of entry and exit dynamics in the export market for the sensitivity of aggregate trade flows to exchange rate changes. The paper did not focus on the characteristics of the firms that enter or exit the export market, nor did it look at the implications of being an exporter for firm performance. Recent work in this area by Bernard and Jensen (1999), Aw, Chen and Roberts (1997) Roberts, Sullivan and Tybout (1995) using also large micro databases for a number of different countries has discovered a number of interesting facts about the behavior of exporting firms in response to structural adjustments as well as the interactions between productivity, employment, sales growth and export performance. Continuing work in this direction will help us better understand the dynamics of successful participation in international markets. 


\section{Data Appendix}

All data on firm characteristics come from the Encuesta de Estrategias Empresariales database. This database contains a longitudinal sample from 1990 to 1997 of Spanish manufacturing firms. The data are collected by the Fundación Empresa Pública for the Spanish Ministry of Industry. The initial sample is of 2188 firms and the sample is representative of the population of firms in Spanish manufacturing industry. Every year firms are added to replace non-respondent or non-existing firms so as to maintain the overall representativeness of the sample. The database is composed of a long questionnaire administered every five years (the first one was in 1990) and smaller annual follow-up questionnaires. All of the variables used were collected annually with the exception of the shares of firm export to different destination markets, which was collected only in 1990 and 1994.

Exchange Rate Data: bilateral exchange rates are indexes of bilateral nominal exchange rates $(1985=100)$. The effective firm-specific exchange rates are computed as a weighted average of these bilateral indexes with the weights being the share of total exports to each individual market. For exporting firms in 1990 or 1994 these weights were obtained directly from the sample broken down by the percentage of the firm exports to the EU, other OECD countries and the rest of the world. If the firm was an exporter in 1990 and 1994 an average market from these two periods was obtained. The bilateral exchange rates used for these markets were the peseta/ECU (for EU exports), the peseta/US\$ (for other OECD countries) and the IMF nominal effective exchange rate index (line NEUR). For other firms, industry-specific exchange rates were computed using the bilateral exchange rates of the four largest destination markets of Spanish export in each industry in 1990. The weights were the share of each of these markets in the total exports of the industry to those four markets. We checked the sensitivity of the exchange rate series to the base year of 1985 by also normalizing the index to $1990=100$. The industry trade data were obtained from the IMF Direction of Trade Statistics, while all bilateral exchange rates are period averages from the IMF, International Financial Statistics.

\section{References}

Arellano, Manuel and Steve Bond (1991): "Some Tests of specification for panel data: Monte Carlo and an application to employment equations", Review of Economic Studies, Vol. 58, pp. 277-297.

Aw, Bee Yan, Xiaomin Chen and Mark J. Roberts (1997): "Firm-level Evidence on Productivity Differentials, Turnover, and Exports in Taiwanese Manufacturing", NBER Working Paper, No. 6235, October.

Baldwin, Richard (1988): "Hysteresis in Import Prices: The Beachhead Effect", American Economic Review, Vol. 78, September, pp. 773-785.

Baldwin, Richard and Paul Krugman (1989): "Persistent Trade Effects of Large Exchange Rate Shocks", The Quarterly Journal of Economics, Vol. 104, November, pp. 635-654.

Bernard, Andrew and J. Bradford Jensen (1999): "Exceptional Exporter Performance: Cause, Effect or Both?", Journal of International Economics, Vol. 47. 
Butler, J.S. and Robert Moffitt (1982): “A Computationally Efficient Quadrature Procedure for the One-Factor Multinomial Probit Model”, Econometrica, Vol. 50, May, pp. 761-764.

Campa, José M. (1993): "Entry by Foreign Firms in the United States under Exchange Rate Uncertainty", The Review of Economics and Statistics, Vol. 75, November, pp. 614-622.

Campa, José M. and P.H. Kevin Chang (1996): “Arbitrage-Based Tests of Target-Zone Credibility: Evidence from ERM Cross-Rate Options", American Economic Review, Vol. 86, September, pp.726-740.

Caves, Richard E. (1990): "Exchange Rate Movements and Foreign Direct Investment in the United States", in David B. Audretsch and Michael P. Claudon (eds.), The Internationalization of U.S. Markets (New York), pp. 199-228.

Dixit, Avinash (1989): "Hysteresis Import Penetration, and Exchange Rate Pass-through", The Quarterly Journal of Economics, Vol. 194, May, pp. 205-228.

Dixit, Avinash (1992): "Investment and Hysteresis", Journal of Economic Perspectives, Vol. 6, Winter, pp. 107-132.

Dixit, Avinash (1993): "Irreversible Investment and the Stability of the J-Curve", Japan and the World Economy, forthcoming.

Dixit, Avinash and Robert Pindyck (1994): Investment Under Uncertainty, Princeton University Press.

Eckstein, Zvi and Kenneth I. Wolpin (1989): "The Specification and Estimation of Dynamic Stochastic Discrete Choice Models: A Survey", The Journal of Human Resources, Vol. 24, Fall, pp. 562-598.

Froot, Kennet and Paul Klemperer (1989): "Exchange Rate Pass-Through When Market Share Matters", American Economic Review, Vol. 79, September, pp. 637-654.

Gagnon, Joseph (1993): "The Effect of Exchange Rate Volatility on the Volume of International Trade", Journal of International Economics.

Giovannini, Alberto (1988): "Exchange Rates and Traded Good Prices", Journal of International Economics.

Heckman, James (1981a): "Heterogeneity and State Dependence", in Sherwin Rosen (ed.) Studies in Labor Markets, Chicago: University of Chicago Press.

Heckman, James (1981b): "The Incidental Parameters Problem and the Problem of Initial Conditions in Estimating A Discrete Time-Discrete Data Stochastic Process", in Charles Manski and Daniel McFadden (eds.), The Structural Analysis of Discrete Data, Cambridge: MIT Press.

Huerta, Emilio and José M. Labeaga (1992): “Análisis de la Decisión de Exportar: Una Aproximación con Datos Microeconómicos”, Investigaciones Económicas, Supplement, pp. 41-47. 
Maddala, G.S. (1987): "Limited Dependent Variable Models Using Panel Data", The Journal of Human Resources, Vol. 22, Summer, pp. 307-338.

Manski, C. (1990): "Nonparametric Bounds on Treatment Effects", American Economic Review Papers and Proceedings, Vol. 80, May, pp.319-323.

Ministerio de Industria y Energía [MINER] (1992): Un Panorama de la Industria Española, Madrid.

Parsley, David C. and Shang-Ji Wei (1993): "Insignificant and Inconsequential Hysteresis: The Case of U.S. Bilateral Trade", The Review of Economics and Statistics, Vol. 75, November, pp. 606-613.

Roberts, Mark and James Tybout (1997): "An Empirical Model of Sunk Costs and the Decision to Export”, American Economic Review, Vol. 87, September, pp. 545-564.

Roberts, Mark, Theresa A. Sullivan and James Tybout (1995): "Micro Foundations of Export Supply: Evidence from Colombia, Mexico and Morocco", Pennsylvania State University Working Paper.

Rust, John (1993): "Structural Estimation of Markov Decision Processes", in R. Engle and D. McFadden, eds. Handbook of Econometrics, Vol. 4, Amsterdam: North-Holland.

Wolpin, Kenneth (1987): "Estimating a Structural Search Model: The Transition from School to Work", Econometrica, Vol 55, pp. 801-818. 


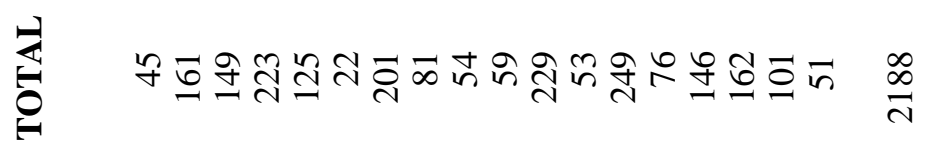

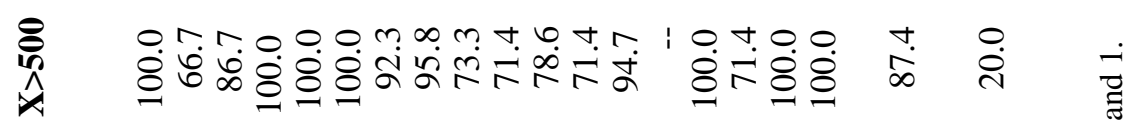

8.

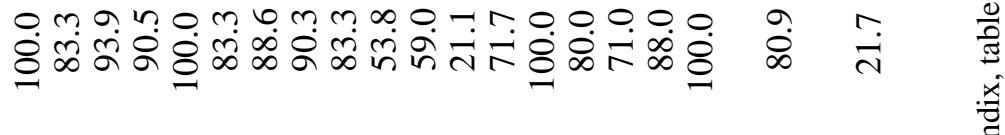

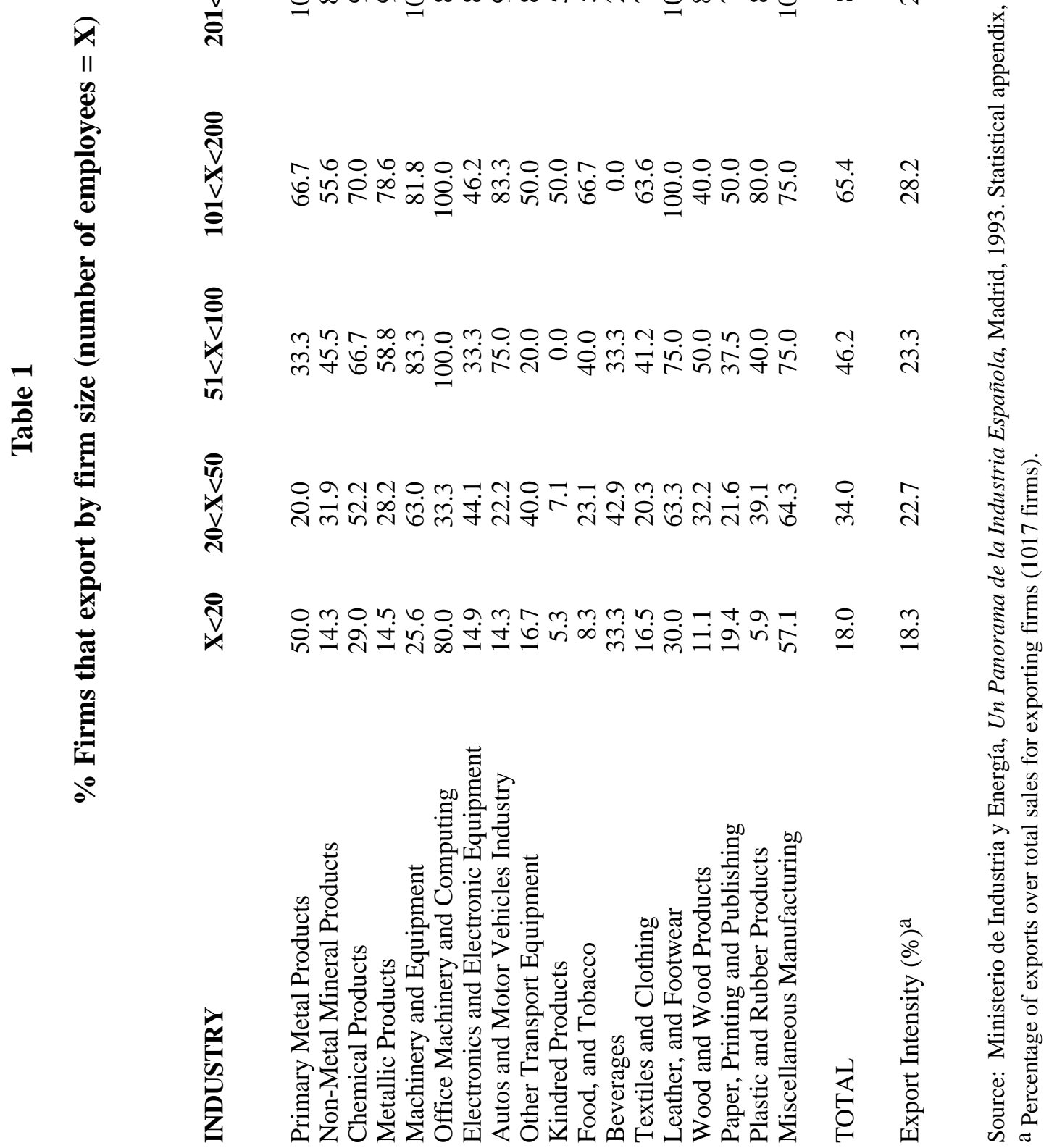




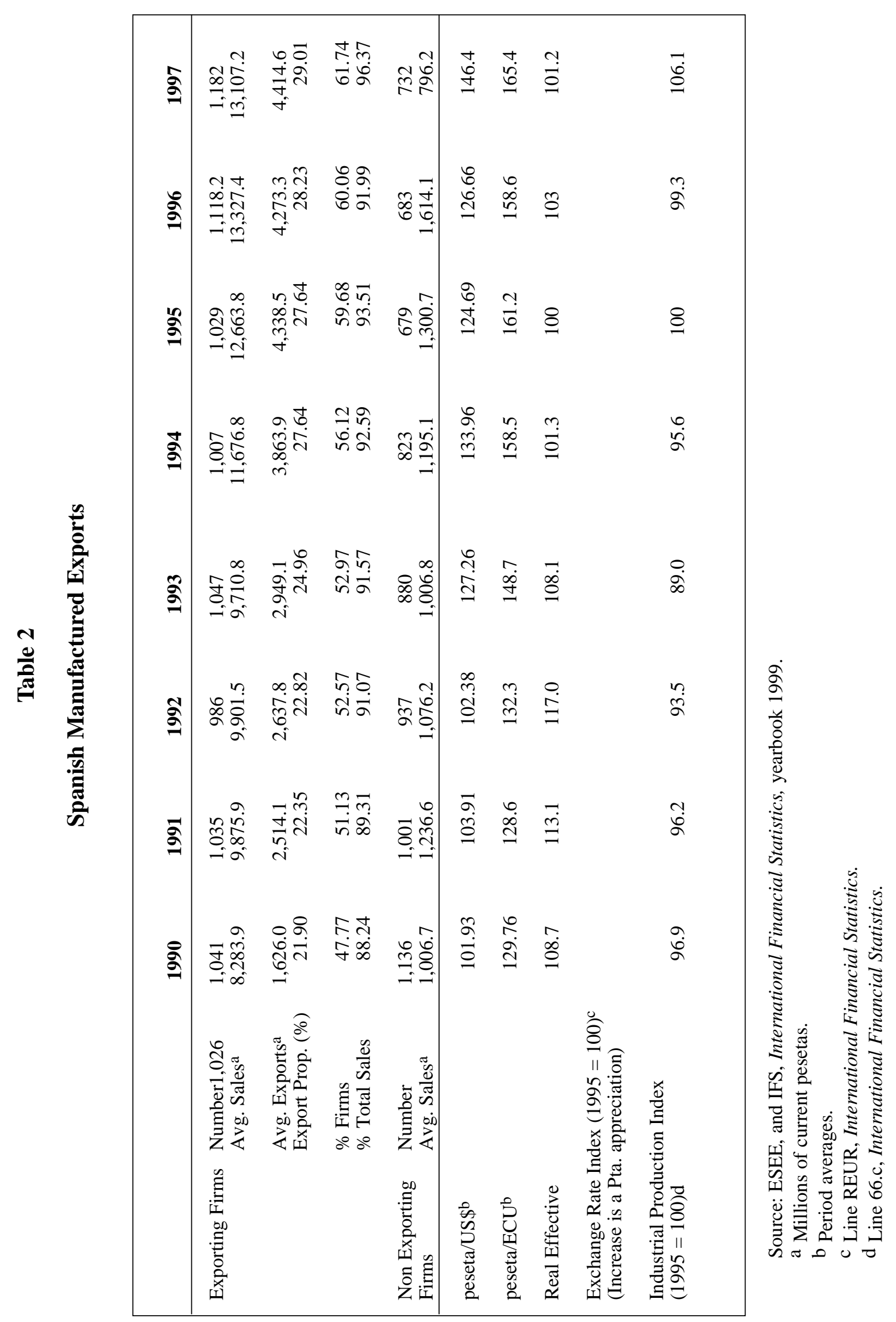



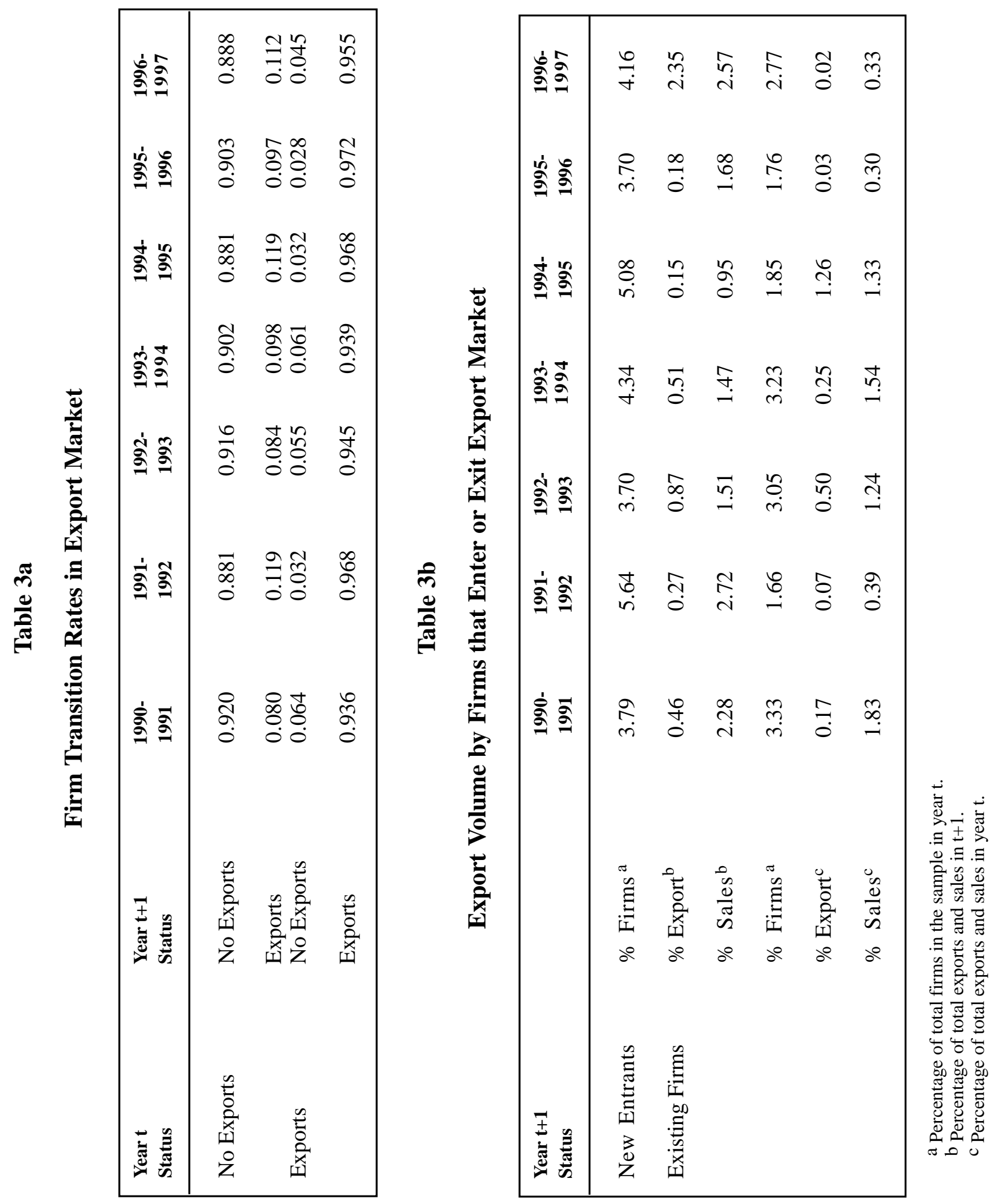


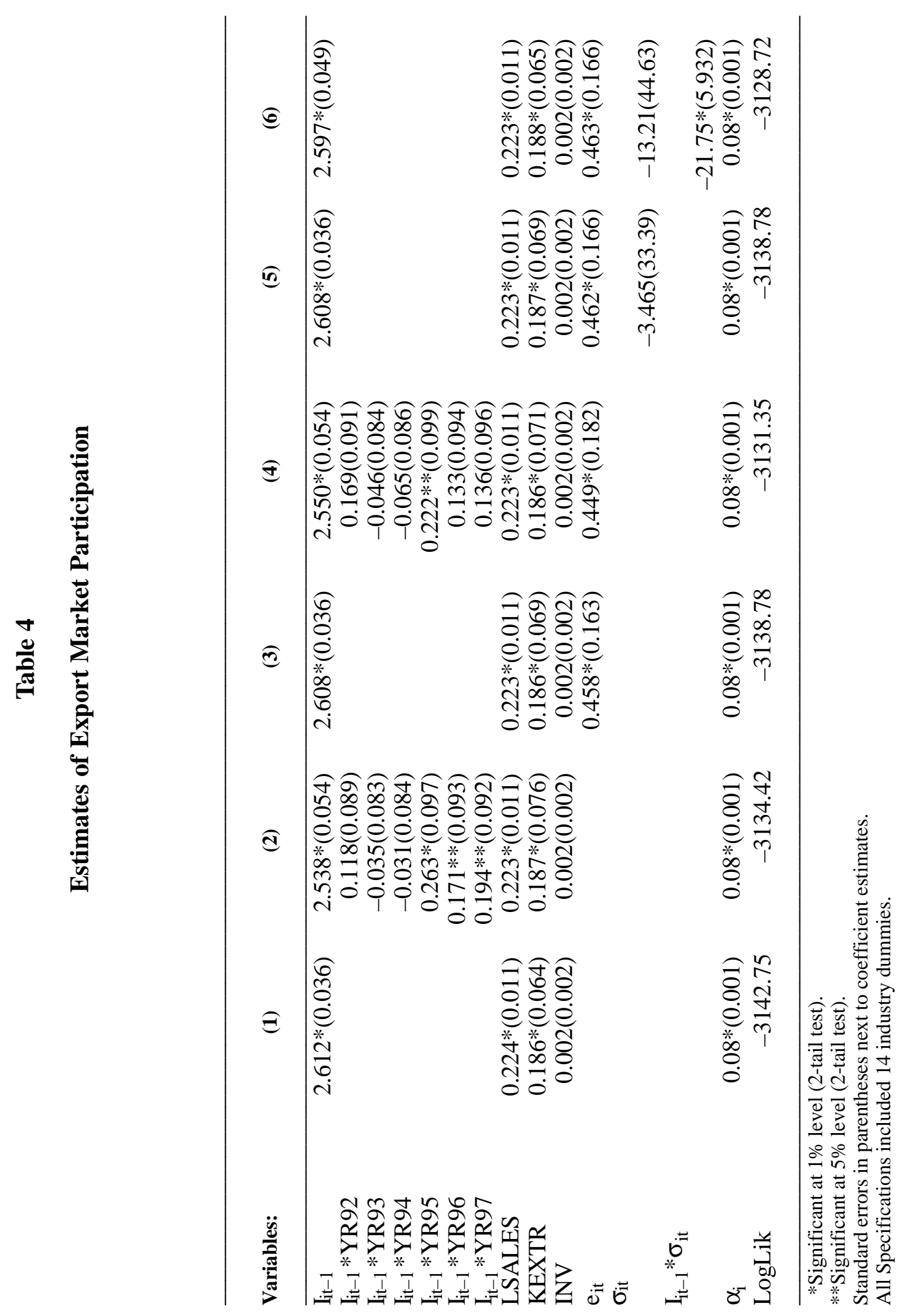


Table 5

Estimates of Export Supply Equation

\begin{tabular}{|c|c|c|c|c|}
\hline Variables: & (1) & (2) & (3) & $(4)^{b}$ \\
\hline LSALES & $1.116^{*}(0.018)$ & $1.112 *(0.018)$ & $1.110 *(0.018)$ & $0.417 *(0.028)$ \\
\hline KINT & $0.121^{* *}(\mathrm{O} .047)$ & $0.114 * *(0.049)$ & $0.115(0.048)$ & $0.076 * *(0.037)$ \\
\hline INV & $-0.001(0.002)$ & $-0.001(0.002)$ & $-0.001(0.002)$ & $-0.001(0.002)$ \\
\hline WAGES & & $-0.658(2.724)$ & & $-0.753(2.630)$ \\
\hline$e_{i t}$ & $0.726 *(0.099)$ & $0.763 *(0.126)$ & $0.786 *(0.104)$ & $0.609 *(0.104)$ \\
\hline$\sigma_{i t}$ & & & $-0.431(0.185)$ & $0.528(0.474)$ \\
\hline$Y_{\text {it-1 }}$ & & & & $0.576 *(0.009)$ \\
\hline Lambda $^{a}$ & $-0.436 *(0.029)$ & $-0.452 *(0.032)$ & $-0.444 *(0.030)$ & $-1.842 *(0.623)$ \\
\hline$\sigma \mathrm{u} / \sigma_{\mathrm{u}}+\sigma_{\mathrm{z}}$ & 0.780 & 0.776 & 0.780 & 0.421 \\
\hline
\end{tabular}

*Significant at $1 \%$ level.

**Significant at $5 \%$ level.

a The values of this variable are estimated using equation (6) in table 4 .

$\mathrm{b}^{\mathrm{b}}$ Estimated using the Arellano and Bond (1991) estimator.

Standard errors in parentheses next to coefficient estimates.

All Specifications included 14 industry dummies and 7 year dummies. 
Table 6

Estimates of Export Supply Elasticity to Exchange Rates

\begin{tabular}{|c|c|c|c|c|c|}
\hline & \multirow{2}{*}{$\begin{array}{c}\text { Full } \\
\text { Sample }\end{array}$} & \multicolumn{4}{|c|}{ Quartile of the Sample Distribution of Domestic Sales } \\
\hline & & 1st. & 2nd. & 3rd. & 4th. \\
\hline $10 \%$ Peseta Depreciation & $7.7 \%$ & $9.7 \%$ & $8.0 \%$ & $7.2 \%$ & $6.7 \%$ \\
\hline Intensive & $79 \%$ & $63 \%$ & $77 \%$ & $85 \%$ & $92 \%$ \\
\hline Extensive & $21 \%$ & $37 \%$ & $23 \%$ & $15 \%$ & $8 \%$ \\
\hline $20 \%$ Peseta Depreciation & $15.2 \%$ & $19.2 \%$ & $15.7 \%$ & $14.2 \%$ & $13.2 \%$ \\
\hline Intensive & $80 \%$ & $64 \%$ & $78 \%$ & $86 \%$ & $89 \%$ \\
\hline Extensive & $20 \%$ & $36 \%$ & $22 \%$ & $14 \%$ & $11 \%$ \\
\hline $10 \%$ Peseta Appreciation & $-7.9 \%$ & $-9.9 \%$ & $-8.2 \%$ & $-7.3 \%$ & $-6.8 \%$ \\
\hline Intensive & $78 \%$ & $62 \%$ & $75 \%$ & $83 \%$ & $90 \%$ \\
\hline Extensive & $22 \%$ & $38 \%$ & $25 \%$ & $17 \%$ & $10 \%$ \\
\hline $20 \%$ Peseta Appreciation & $-16.0 \%$ & $-20.1 \%$ & $-16.6 \%$ & $-14.8 \%$ & $-13.7 \%$ \\
\hline Intensive & $76 \%$ & $61 \%$ & $74 \%$ & $83 \%$ & $89 \%$ \\
\hline Extensive & $24 \%$ & $39 \%$ & $26 \%$ & $17 \%$ & $11 \%$ \\
\hline
\end{tabular}

Calculations assume a PPP exchange rate as of June 1989. All estimates are based on estimated coefficients from equation [3] in Table 5 and evaluated at the mean values of the independent variables for each sample. 